Organizational Images and Member Identification

Author(s): Jane E. Dutton, Janet M. Dukerich and Celia V. Harquail

Source: Administrative Science Quarterly, Vol. 39, No. 2 (Jun., 1994), pp. 239-263

Published by: Sage Publications, Inc. on behalf of the Johnson Graduate School of Management, Cornell University

Stable URL: http://www.jstor.org/stable/2393235

Accessed: 26-02-2015 21:08 UTC

Your use of the JSTOR archive indicates your acceptance of the Terms \& Conditions of Use, available at http://www.jstor.org/page/info/about/policies/terms.jsp

JSTOR is a not-for-profit service that helps scholars, researchers, and students discover, use, and build upon a wide range of content in a trusted digital archive. We use information technology and tools to increase productivity and facilitate new forms of scholarship. For more information about JSTOR, please contact support@jstor.org.

Sage Publications, Inc. and Johnson Graduate School of Management, Cornell University are collaborating with JSTOR to digitize, preserve and extend access to Administrative Science Quarterly. 


\section{Organizational Images and Member \\ Identification}

\author{
Jane E. Dutton \\ University of Michigan \\ Janet M. Dukerich \\ University of Texas at Austin \\ Celia V. Harquail \\ University of Michigan
}

We develop a model to explain how images of one's work organization shape the strength of his or her identification with the organization. We focus on two key organizational images: one based on what a member believes is distinctive, central, and enduring about his or her organization and one based on a member's beliefs about what outsiders think about the organization.

According to the model, members assess the attractiveness of these images by how well the image preserves the continuity of their self-concept, provides distinctiveness, and enhances self-esteem. The model leads to a number of propositions about how organizational identification affects members' patterns of social interaction.

Members vary in how much they identify with their work organization. When they identify strongly with the organization, the attributes they use to define the organization also define them. Organizations affect their members through this identification process, as shown by the comments of a $3 \mathrm{M}$ salesman, quoted in Garbett (1988: 2):

I found out today that it is a lot easier being a salesman for $3 \mathrm{M}$ than for a little jobber no one has ever heard of. When you don't have to waste time justifying your existence or explaining why you are here, it gives you a certain amount of self-assurance. And, I discovered I came across warmer and friendlier. It made me feel good and enthusiastic to be "somebody" for a change.

This salesman attributes his new, more positive sense of self to his membership in $3 \mathrm{M}$, a well-known company. What he thinks about his organization and what he suspects others think about his organization affects the way that he thinks about himself as a salesperson.

This paper explores the kind of connection that salesman had with 3M: a member's cognitive connection with his or her work organization derived from images that each member has of the organization. The first image, what the member believes is distinctive, central, and enduring about the organization, is defined as perceived organizational identity. The second image, what a member believes outsiders think about the organization, is called the construed external image (Dutton and Dukerich, 1991). Our model proposes that these two organizational images influence the cognitive connection that members create with their organization and the kinds of behaviors that follow.

When a person's self-concept contains the same attributes as those in the perceived organizational identity, we define this cognitive connection as organizational identification. Organizational identification is the degree to which a member defines him- or herself by the same attributes that he or she believes define the organization. The $3 \mathrm{M}$ salesman reflects his organizational identification when he describes himself as innovative and successful, just like the $3 \mathrm{M}$ organization. A person is strongly identified with an organization when (1) his or her identity as an organization member is more salient than alternative identities, and (2) his or her self-concept has many of the same characteristics he or she believes define the organization as a social group. 
We build our arguments on the core assumption that people's sense of membership in the social group "the organization" shapes their self-concepts (Tajfel and Turner, 1985; Ashforth and Mael, 1989; Kramer, 1991).

Organizational scholars have explored how a person's self-concept is shaped by membership in occupational groups (Van Maanen and Barley, 1984) and work groups (Alderfer and Smith, 1982). Here we consider how a person's self-concept is shaped by the knowledge that she or he is a member of a specific organization.

The images that members hold of their work organizations are unique to each member. A person's beliefs therefore may or may not match a collective organizational identity that represents the members' shared beliefs about what is distinctive, central, and enduring about their organization (Albert and Whetten, 1985). In addition, each member's own construal of the organization's external image may or may not match the reputation of the organization in the minds of outsiders. We focus on the relationship between a member's individual images of his or her organization as a social group and the effects of those images on the strength of organizational identification and member behavior.

\section{Linking Organizational Images to Members' Self-Concepts}

A person's well-being and behavior are affected both by the attributes they ascribe to themselves and by those they believe others infer about them from their organizational membership. As the quote from the $3 \mathrm{M}$ salesman illustrates, organizational membership can confer positive attributes on its members, and people may feel proud to belong to an organization that is believed to have socially valued characteristics. When members believe that outsiders see the organization in a positive light, they "bask in the reflected glory" of the organization (Cialdini et al., 1976: 366). Strong organizational identification may translate into desirable outcomes such as intraorganizational cooperation or citizenship behaviors.

Organizational membership can also confer negative attributes on a member. If members interpret the external organizational image as unfavorable, they may experience negative personal outcomes, such as depression and stress. In turn, these personal outcomes could lead to undesirable organizational outcomes, such as increased competition among members or reduced effort on long-term tasks. Over time, members may either disengage themselves from prior organizational roles (Kahn, 1990) or exit the organization (Hirschman, 1970). Just such a negative external organizational image has created problems for members of the Port Authority of New York and New Jersey (PA). For more than a decade, the PA has struggled with what to do about the rising number of homeless people who seek shelter in its transportation facilities, including the Bus Terminal. As problems with the homeless became more severe, the media increasingly depicted the PA's facilities as dangerous and dirty and the PA organization as ineffective and inhumane. Negative press about the PA indirectly hurt the employees. When PA members began to construe the 
organization's external image in these negative and socially undesirable terms, they felt demeaned and hurt by the criticism that they inferred from outsiders. Through a story told about one PA member at a cookout, another member emphasized the connection between organizational actions, a negatively construed external image, and the member's self-concept:

You know, the guy that's running the Lincoln Tunnel doesn't have a full perception of how the Bus Terminal or the homeless impact what he does on a day-to-day basis. But the minute he leaves and he goes to the cookout in his neighborhood and he meets somebody and the person says, "What do you do for a living?'" "Oh, I work for the Port Authority." They say, "How can you stand that Bus Terminal, what can you do?" That's the name. That's the symbol of the Port Authority. It's the standard bearer. And you know, so personally everybody that's involved in any aspect of working for the Port Authority is identified with that place, and with that issue. (Dutton and Dukerich, 1991: 538)

An employee who worked far away from the homeless issue in the Bus Terminal still felt that actions in one segment of the organization affected how others saw him.

Similarly, Exxon employees felt that the public regarded them in a negative light after the Valdez oil spill. Because the press made Exxon's inadequate action so visible and public, Exxon employees found that they were expected to defend the company's actions in social situations. As described in Fanning (1990: 25):

But the targets of the most scorn at the moment are probably oil-company executives. Take the case of Exxon corporation. It was only recently that executives at that company were able to admit their place of employment without the fear of being attacked by environmentalists infuriated by the company's handling of last year's oil spill at Prince William Sound. Slowly but surely, Exxon executives began to reappear at cocktail parties across the country, and occasionally, even had a good time.

Even employees working at Exxon's Credit Card Center did not escape the public's wrath: They received oil-soaked, cut-up credit cards from angry customers. As one newspaper explained: "Employees, confronted daily by criticisms of Exxon in the media and by friends and family members, are questioning their faith in the corporate giant" (Star Ledger, 1989: 3). When people identify strongly with their work organizations, they experience such threats personally (Schwartz, 1987).

As the Port Authority and Exxon examples suggest, outsiders actively judge employees by the characteristics attributed to the organization through its public reputation. Inside the organization, members interpret and infer the reputation of their organization and react to the external image they construe of their organization. As the media publicizes information about an organization, public impressions of the organization and of the organization's members become part of the currency through which members' self-concepts and identification are built or are eroded.

\section{Organizational Identification}

Members become attached to their organizations when they incorporate the characteristics they attribute to their 
organization into their self-concepts. The self-concept is an interpretive structure that mediates how people behave and feel in a social context (Gecas, 1982; Schenkler, 1985; Markus and Wurf, 1987) and refers to "the totality of self-descriptions and self-evaluations subjectively available to an individual" (Hogg and Abrams, 1988: 24). A person's self-concept may be composed of a variety of identities, each of which evolves from membership in different social groups, such as a social group based on race, gender, or tenure (Stryker and Serpe, 1982; Breakwell, 1986). But self-concepts are also influenced by memberships in social groups such as work organizations (Ashforth and Mael, 1989), through which a member may come to identify with the organization. While some researchers have focused on organizational identification as value congruence between a member and his or her organization (e.g., Hall, Schneider, and Nygren, 1970; Lee, 1971; Hall and Schneider, 1972), we focus on the cognitive connection between the definition of an organization and the definition a person applies to him- or herself, viewing identification as a process of self-definition (Brown, 1969). Defining organizational identification as a cognitive link between the definitions of the organization and the self is consistent with attitudinal approaches to commitment (e.g., Porter et al., 1974; Mowday, Porter, and Steers, 1982). As part of the commitment process, the level of organizational identification indicates the degree to which people come to see the organization as part of themselves. Organizational identification is one form of psychological attachment that occurs when members adopt the defining characteristics of the organization as defining characteristics for themselves.

Organizational identification can have both positive and negative effects on a member's sense of self. Organizational identification as defined here does not necessarily connote a pride in affiliation with the organization-a characteristic that is central in Kelman's (1958) view of identification and is used by O'Reilly and Chatman (1986) in their work on identification as a means for psychological attachment. As illustrated by the discomfort felt by Exxon executives and by PA members, identification with an organization can result in feelings of shame, disgrace, or embarrassment.

The strength of a member's organizational identification reflects the degree to which the content of the member's self-concept is tied to his or her organizational membership. When organizational identification is strong, a member's self-concept has incorporated a large part of what he or she believes is distinctive, central, and enduring about the organization into what he or she believes is distinctive, central, and enduring about him- or herself. When organizational identification is strong, the organization-based content of a member's self-concept is salient and central (Gergen, 1968; Stryker and Serpe, 1982), other identities in the self-concept have receded, and organizational membership is a central and frequently used basis for self-definition (Kramer, 1991).

Several researchers have described the formation of and change in a member's organizational identification.

Borrowing from Tajfel and Turner (1985), Ashforth and Mael 
(1989) described organizational identification as a process of self-categorization. They proposed that organizational identification strengthens when members categorize themselves into a social group-in this case the organization-that has distinctive, central, and enduring attributes. The premise that identification is caused by self-categorization provides the foundation for our model of organizational identification. The model focuses on two key images that organizational members have of their work organization-perceived organizational identity and construed external image.

\section{A MODEL OF MEMBER IDENTIFICATION}

Several points support the idea that organizations have collective identities, consisting of the beliefs that members share as distinctive, central, and enduring. First, it is common practice for organizational leaders to articulate and claim what is distinctive, central, and enduring about their organization (Pfeffer, 1981; Albert and Whetten, 1985). Whether or not these claims of distinctiveness are empirically valid (e.g., Martin et al., 1983) is less important than the fact that powerful organizational members engage in communication and influence processes in an effort to create a collective identity for members. Organizations have a broad repertoire of cultural forms such as rituals, symbols, ceremonies, and stories that encode and reproduce shared organizational patterns of behavior and interpretation (Allaire and Firsirotu, 1984). Rituals, ceremonies, and stories objectify and communicate the collective organizational identity to organizational members.

Distinctive organizational attributes often remain hidden to members until the organization's collective identity is challenged (Albert and Whetten, 1985; Fiol, 1991) or until some precipitating event calls organizational actions or performance into question (Ginzel, Kramer, and Sutton, 1993). Sometimes major stakeholders' actions or changes in the organization's environment such as regulatory changes or competitive moves can cause the organization's collective identity to surface. The collective organizational identity also becomes more salient when members believe that the organization's actions are inconsistent with its collective identity (e.g., when a social service agency buys expensive office furniture) or when individual members act in ways that contradict the collective organizational identity (e.g., when professors in a teaching college consistently miss class). In these cases, organizational or individual actions interrupt the flow of normal organizational routines, prompting individuals to ask, "What is this organization really about?" These actions motivate members to review and acknowledge what they believe defines the organization, and this affects the strength of their connection to the organization.

\section{Perceived Organizational Identity}

Whereas an organization's collective identity represents the set of beliefs that members share, perceived organizational identity refers to the beliefs of a particular individual organizational member. Because organizations imperfectly socialize members to a collective view, perceived 
organizational identity may depart from the organization's collective identity. The perceived organizational identity-a member's beliefs about the distinctive, central, and enduring attributes of the organization-can serve as a powerful image influencing the degree to which the member identifies with the organization.

\section{Perceived Organizational Identity and Identification}

The degree to which the perceived organizational identity affects a person's identification level depends on the attractiveness of this image to the person, which requires a subjective evaluation. An attractive perceived organizational identity strengthens a member's identification. Stated in proposition form:

Proposition 1 (P1): The greater the attractiveness of the perceived organizational identity, the stronger a person's organizational identification.

Three principles of self-definition-self-continuity, self-distinctiveness, and self-enhancement-account for the attractiveness of an organizational image and explain why it strengthens identification.

\section{Self-continuity and the attractiveness of the perceived organizational identity. People generally want to maintain the continuity of their self-concepts over time and across situations (Steele, 1988). A member's perception of his or her organization's identity adds or subtracts from the continuity that he or she experiences in his or her self-concept over time. Two arguments support the idea that similarity between the self-concept and perceived organizational identity enhances continuity and that continuity of self strengthens a member's identification by making the perceived organizational identity more attractive.}

First, people find a perceived organizational identity more attractive when it matches their own sense of who they are (i.e., their self-concept) simply because this type of information is easy to process and understand. Social psychologists argue that people attend to and process "self-relevant" information differently than "self-irrelevant" information (Markus and Wurf, 1987). The general finding is that people more easily focus on, process, recognize, and retrieve self-relevant than self-irrelevant information. The ease of recognizing, processing, and retrieving self-relevant information makes organizational identities that match the self more attractive than organizational identities that do not match the self.

Second, when a person's self-concept and the perceived organizational identity are similar, a member is drawn to the organization because it provides easy opportunities for self-expression (Shamir, 1991). People are drawn to organizations that allow them to exhibit more of themselves and to enact a fuller range of characteristics and values in their self-concept. For example, a triathlete who values physical prowess and involvement in competitive athletics will be drawn more to a shoe manufacturer like Nike, which encourages its employees to work out on company time, than to another shoe manufacturer that is involved in community arts associations. 
People value self-integrity and a sense that they are internally coherent (Steele, 1988). To maintain this integrity, people want to act authentically (Gecas, 1982), expressing the personality characteristics they think they have and which they value. People are drawn to organizations in which they can express themselves rather than hide the contents of their self-concept. This assertion is built on an assumption that "humans are not only pragmatic and goal oriented but also self-expressive" (Shamir, House, and Arthur, 1993: 580). For example, a vegetarian journalist will be drawn more to Vegetarian Times than to Bow Hunter magazine, since the former organization is more likely to provide the journalist with opportunities to express a sense of him- or herself as a supporter of animal rights. We see this relationship in Kunda's (1992) account of how engineers identified with Tech, where they could express more of the characteristics they valued about themselves. The engineers enjoyed Tech's technical orientation because it matched their own. As Kunda (1992: 177) explained: "Similarly, many engineers acknowledge attachment to Tech's technology, which they view as unique and through that, to the company. Says one: 'Once you've worked with Tech products in a Tech environment, it's hard to go to anything else. They just adjust so much better. It's an engineer's dream-if he's into technology'."

Chatman and her colleagues found similar results for behavioral outcomes. In a study of accounting recruits, Chatman (1991) found that a strong fit between the pattern of organizational values and members' values predicted members' satisfaction and intent to stay with the organization a year later. In addition, an increase in person-organization fit over the first year was significantly and positively related to members' satisfaction levels. In two different empirical contexts, O'Reilly and Chatman (1986) found that people who secured an attachment to the organization based on value-congruency (what they called attachment based on internalization) reported high intentions to stay with the organization (Study 1), and greater internalization was associated with lower actual turnover (Study 1 and Study 2). O'Reilly, Chatman, and Caldwell (1991) reported similar results in another series of studies. In all three studies, the greater the degree of fit between the person and the organization, the greater the degree of similarity between the perceived organizational identity and a person's self-concept. These results suggest that greater person-organization fit resulted in attitudes and behaviors consistent with stronger identification and lead to our second proposition:

Proposition 2 (P2): The greater the consistency between the attributes members use to define themselves and the attributes used to define an organizational image (e.g., perceived organizational identity), the stronger a member's organizational identification.

The link between continuity, the attractiveness of the perceived organizational identity, and levels of members' organizational identification helps members maintain a stable self-concept over time. They identify strongly with their organization when their prior sense of self resembles what 
they believe is central, enduring, and distinctive about their organization. This relationship makes organizational identification a reciprocal and recursive process. Members who believe the organization is similar to them strengthen the self-associations that were already in place before they became organizational members.

\section{Self-distinctiveness and the attractiveness of the perceived organizational identity. Theories of social identity assert that people seek to accentuate their own distinctiveness in interpersonal contexts (Tajfel and Turner, 1985). As a result, members will find organizations attractive when their social identities there provide them with a sense of distinctiveness. A salesperson working for $3 \mathrm{M}$ may feel that his or her identification with the organization is a basis for distinctiveness relative to other salespeople working for organizations lacking a clear identity. Kunda (1992: 177) described how engineers in Tech identified with the organization because of its uniquely honest business practices. He related the experience of one project manager:}

I worked for a while for a company that built on those contracts. I worked on the ABM radar. It's not so much that I mind what the products end up doing. No. But all the dishonesty-the excessive costs, the stupidity, the unnecessary work-it really got me down. The norm was: hide the basic specs, follow the letter of the law and produce garbage, then get another contract. Disgusting stuff. Like telling reliability engineers to cook figures. At Tech at least we give customers an honest product. They get what they pay for. Most of the time I feel good about that.

Borrowing from social identity theory, Ashforth and Mael (1989: 24) asserted that "the distinctiveness of the group's [in this case the organization's] values and practices in relation to those of comparable groups increase members' tendency to identify with the organization." Mael and Ashforth (1992) found that alumni of a religious college who perceived their university as distinctive in attitudes, values, and practices had high levels of organizational identification, in terms of a perception of oneness or belongingness to an organization. Ashforth and Mael (1989) argued that this form of organizational identification is associated with cognitive identification, when a person defines him- or herself in terms similar to the organization. Organizational members who believe their organization has a distinctive culture, strategy, structure, or some other configuration of distinctive characteristics are likely to experience strong levels of organizational identification. The above arguments lead to the following proposition:

Proposition 3 (P3): The greater the distinctiveness of an organizational image (e.g., perceived organizational identity) relative to other organizations, the stronger a member's organizational identification.

Self-enhancement and the attractiveness of the perceived organizational identity. When members associate with organizations that have an attractive perceived identity, it enhances their self-esteem as they acquire a more positive evaluation of self. Consistent with past theory, we define self-esteem in terms of the degree to which one likes oneself (Brockner, 1988). For example, if members believe their work organization is defined by qualities associated with 
competence, power, efficacy, virtue, or moral worth (Gecas, 1982), they are likely to see the perceived organizational identity as attractive. Association with an organization possessing these qualities enhances members' self-esteem because this affiliation provides them with an opportunity to see themselves with these positive qualities, strengthening the degree to which a member likes him- or herself. The link between the attractiveness of the perceived organizational identity and self-esteem implies that members personally experience any decreases or increases in the attractiveness of organizational images.

In the larger study of the Port Authority from which Dutton and Dukerich's (1991) research was drawn, one-third of the respondents noted that the organization was distinctive in terms of being a first-class, high-quality institution. This conception of perceived organizational identity was an important source of self-esteem for Port Authority members. The PA's failure to act on the issue of the homeless raised questions about the basis for the organization's distinctiveness, and members experienced these questions as threats to a positive evaluation of self. As one facility manager expressed it:

But I've always felt that the Port Authority is ... and part of our self-image is, as I put my fingers on it, that we do things a little better than other public agencies. There's a whole psyche that goes with that ... and that's why, when there's time like now, when times get tough, people are nervous a bit, because that goes to their self-image, which is that the Port Authority and therefore, we do things first class.

This example points to how perceived organizational identity and the evaluation of self by members are linked to members' self-esteem. It leads to the fourth proposition:

Proposition 4 (P4): The more an organizational image (e.g., perceived organizational identity) enhances a member's self-esteem, the stronger his or her organizational identification.

There is an important reciprocal quality to the relationships described in these propositions. As members increasingly define themselves with characteristics that distinguish the organization, and as organizational identification is strengthened, this identity looks increasingly attractive. The more an employee at Tech takes on an attribute of Tech's identity by defining him- or herself as a uniquely honest person, the more attractive Tech's perceived identity looks. As Ashforth and Mael suggested (1989), one consequence of strong identification with an organization is a strengthening of its antecedents, in this case, the attractiveness of the perceived organizational identity. Another factor that affects the attractiveness of perceived organizational identity is a person's involvement with the organization.

Level of contact and the attractiveness of the perceived organizational identity. The attractiveness of the perceived organizational identity varies with a member's length of tenure and intensity of exposure to the organization. As members gain tenure in an organization, they increase the level and breadth of exposure to the collective organizational identity, making these organizational attributes more accessible in memory (Bruner, 1957). Through the passage 
of time, doing organizational work, and intense daily interactions, people come to know themselves as members of the organization (Foote, 1953). Greater contact with the organization increases a member's perceptual readiness (Bruner, 1957) to categorize and define him- or herself as a member of this social group. The longer one remains with an organization, the more salient this group membership is for self-categorization and the more primary is organizational membership as opposed to other group memberships (Kramer, 1991).

O'Reilly and Chatman's (1986) research provides indirect support for the relationship between levels of contact, attractiveness of the perceived organizational identity, and levels of identification. They found a significant positive correlation between tenure in a university and the degree of pride and ownership that people felt with respect to their employing organization. If we assume that pride and ownership in the organization are associated with the attractiveness of the perceived identity, their studies suggest that intense and long contact with an organization (as reflected by greater tenure) increases the level of attractiveness of the organization's identity, contributing to a greater degree of identification. Mael and Ashforth (1992) also found a significant positive correlation between length of time in school and a person's organizational identification, providing more direct support for this link.

Researchers studying the socialization process (Van Maanen, 1975; Feldman, 1976) have asserted that members of organizations incorporate the meaning of the organization into their self-concept. Over time, members are exposed more and more to the totems or symbols that remind them of their union with the organization (Stern, 1988). Members change their level of inclusion in an organization, moving from the periphery of the organization to the center of things (Van Maanen and Schein, 1979: 222) as they interact with other members. As members experience increasing inclusion and contact with the organization, the attractiveness of the perceived organizational identity increases, strengthening organizational identification. As was the case with the previous proposition, rising levels of identification, in turn, motivate members to increase their levels of contact with the organization:

Proposition 5 (P5): The more contact a member has with an organization (in terms of intensity and duration), the greater the attractiveness of the perceived organizational identity and the stronger the organizational identification.

\section{Construed External Image}

Members' identification is also sensitive to how they think outsiders view the organization. While the perceived organizational identity is a member's assessment of the organization's character, construed external image refers to a member's beliefs about outsiders' perceptions of the organization. The construed external image provides more than just information about the probable social evaluation of the organization. For members, the construed external image answers the question, "Hovv do outsiders think of me because of my association with this organization?" The

248/ASQ, June 1994 
construed external image acts as a potentially powerful mirror, reflecting back to the members how the organization and the behavior of its members are likely being seen by outsiders. This ties in to the concept of the corporate image.

Practitioners and academics use the term "corporate image" in a variety of ways. Consultants use the term "corporate image" to refer to the impression that an organization makes to outsiders and insiders (e.g., Selame and Selame, 1988). Researchers in marketing assert that corporate images matter to a firm's customers (e.g., Arora and Cavusgil, 1985). Human resource researchers study how information shapes the attractiveness of an organization's image during recruiting (e.g., Gatewood, Gowan, and Lautenschlager, 1993). Researchers interested in the processes of organizational impression management describe how various tactics for enhancing organizational image alter how outside parties view the organization and its actions (e.g., Elsbach and Sutton, 1992). Dutton and Dukerich (1991) used the term organizational image to refer to what organizational insiders believe outsiders think is distinctive, central, and enduring about the organization. Here, however, to clarify and distinguish whose beliefs are of interest, we use the term construed external image.

We distinguish between two different uses of the term organizational image: one focusing on the beliefs of outside members, the other focusing on the beliefs of inside members. Organizational reputation refers to outsiders' beliefs about what distinguishes an organization; construed external image captures internal members' own assessment of these beliefs (Dutton and Dukerich, 1991). This distinction between reputation and construed external image is important. Insiders and outsiders to an organization have access to different information about the organization and apply different values and goals in interpreting this information. Distinguishing between construed external image and reputation allows these two organizational images to differ from one another.

Sometimes an organization's reputation and insiders' construed external images are closely aligned. When an organization's reputation is widely disseminated through extensive press or media attention, for example, the organization's reputation is likely to be highly correlated with the external image of the organization construed by insiders. Despite their public media campaigns and the creation of pseudo-events that are planned for the explicit purpose of being reported (Boorstin, 1961), most organizations are unable to align fully outsiders' beliefs about an organization (i.e., reputations) and insiders' readings of these beliefs (i.e., construed external images). Organizational members sometimes have a distorted impression of what others believe, either believing their organization is perceived in a more positive or a more negative light than outsiders see it. Ginzel, Kramer, and Sutton (1993) described how top managers at Dow Corning Wright tried to control the reputational damage to their firm that occurred because of the continued production and sale of silicon breast implants. As their attempts to manage the impressions of external audiences created new reputational crises (e.g., as a 
production problem became a problem of organizational integrity and honesty), top managers seemed unaware of the amount of damage that their reputation had sustained. In this case, the construed external image (by top management and perhaps members more generally at Dow Corning) was more positive than the firm's actual reputation. This inconsistency between reputation and construed external image delayed the firm's crisis response and contributed to the interpretive conflict that top managers experienced as they tried to manage the firm's reputation in the minds of both sympathetic and antagonistic audiences.

\section{Construed External Image and Identification}

The earlier example of Exxon's executives' struggle with social contact at cocktail parties illustrates that organizational members use the construed external image of an organization to assess the social value of their affiliation with an organization. Because construed external image summarizes a member's beliefs about how people outside the organization are likely to view the member through his or her organizational affiliation, the construed external image is a powerful reflection of public opinion. When the construed external image of an organization is assessed as attractive (i.e., members believe the image contains attributes that distinguish the organization in positive, socially valued terms), the construed external image strengthens members' organizational identification.

People try to maintain a positive social identity (Tajfel and Turner, 1985) because positive social identities (1) create self-gratifying social opportunities (Brown, 1969), (2) heighten social prestige (Perrow, 1961; Cheney, 1983; Ashforth and Mael, 1989), (3) facilitate social interaction (Foote, 1953), and (4) create social credits. When members construe the external image as attractive-meaning that they believe this image has elements that others are likely to value-then organizational affiliation creates a positive social identity (Tajfel, 1982) that increases the level of overlap between how a member defines him- or herself and the organization. Empirical research supports this claim. Vardi, Wiener, and Poppa (1989) found that members in an organization that produced a product for the military market in Israel more strongly identified with their organization than members in a matched firm producing a similar product for a commercial market. The firm's positive social role as a manufacturer of products for the military market-a market that is socially valued in Israel_could explain these findings: Members working in the first organization viewed the construed external image of the firm as attractive, which thereby strengthened their identification. This logic and example provide the basis for proposition 6:

Proposition 6 (P6): The greater the attractiveness of an organization's construed external image, the stronger a member's organizational identification.

The same principles of self-definition account for why members are likely to see the construed external image of their work organization as attractive or not: (1) self-continuity, (2) self-distinctiveness, and (3) self-enhancement. 
Self-continuity and the attractiveness of the construed external image. Proposition 2 asserted that members will find organizational images more attractive if they contribute to a consistent sense of self. This proposition is as valid for how members value construed external images as it is for the perceived organizational identity. When members believe outsiders view the organization in terms that are close to how they see themselves, then membership provides an opportunity to maintain a coherent and consistent sense of self.

\section{Self-distinctiveness and the attractiveness of the} construed external image. A construed external image that enhances a member's distinctiveness in interpersonal contexts will also be seen as more attractive, following the logic of proposition 3, which derives from social identity theory. Members gain distinctiveness from their own sense of what uniquely characterizes their work organization (perceived organizational identity) and from what they believe outsiders think about the organization (construed external image). This may be the route by which advertising and public relations efforts affect people's attachments to their work organizations. When these advertising efforts and public image campaigns make insiders believe that outsiders think the organization is unique in some way, these efforts may yield benefits not only in attracting customers, they may also enhance members' commitment by strengthening identification.

\section{Self-enhancement and the attractiveness of the} construed external image. According to proposition 4, the construed external image of an organization can become attractive to a person because it enhances his or her self-evaluation by providing important information about how others are likely to appraise a member's character based on his or her organizational affiliation (Dutton and Dukerich, 1991). People want to maintain a positive self-concept (Turner, 1978; Brockner, 1988). They use an organization's construed external image to estimate the reflected appraisal of outsiders and are drawn to images that portray them as competent and morally virtuous (Gecas, 1982). Thus, if a member believes outsiders are likely to view the organization favorably, the image is attractive. An attractive image encourages further alignment between a member's self-concept and organizational definition. Greenberg (1990) argued, for example, that organizations that are construed as "fair" have members who more strongly identify with it. This may occur because possibilities for self-enhancement are afforded by one's affiliation with such a positively construed external image.

\section{Visibility of Affiliation and Identification}

The relationship between the attractiveness of these organizational images and the strength of identification depends on people's visible affiliation with their work organization. Two sets of arguments support this assertion: one is based on a simple self-perception logic, the other is tied to the logic of impression management.

When people are visibly associated with an organization, they are more frequently reminded of their organizational membership. Visible affiliations, such as those made through 
public organizational roles, serve as vivid reminders of organizational membership (Charters and Newcomb, 1952) and increase the potency of the organization as a source of self-definition (Brown, 1969). These reminders make people's membership in the organization accessible and salient to them (Turner, 1982). When a person is visibly affiliated with an organization, self-perception processes heighten his or her own awareness of the attractiveness of the organization. For perceived organizational identity, the attractiveness of this image will have a greater effect on the strength of a member's identification if he or she is visibly affiliated with the organization:

Proposition 7 (P7): The greater the visibility of a member's affiliation with the organization, the stronger the relationship between the attractiveness of the perceived organizational identity and his or her organizational identification.

The visibility of a member's organizational affiliation can have an even greater moderating effect on the relationship between the attractiveness of the construed external image and member identification because of the motivation to manage impressions. Public knowledge that a person is affiliated with an organization creates expectations about how he or she is likely to behave and the types of attitudes he or she is likely to hold (Tetlock and Manstead, 1985). People expect a member who is visibly affiliated with the Rotary Club to behave in ways and to hold attitudes that are appropriate to Rotarians, whereas people not affiliated with the Rotary Club would not be subject to these expectations. These expectations, and members' awareness of them, encourage members to take on the qualities embodied in the perceived organizational identity. If one is visibly associated with the Rotary Club and this organization's perceived organizational identity includes the attributes of community service, this quality will more likely become part of the member's own self-concept, thus strengthening identification, if the member is visibly affiliated with the organization.

When people have organizational affiliations that are visible, either through physical displays, such as Rotarians' use of lapel pins, or their organizational locations (e.g., having leadership or boundary spanning roles), they are in the position of having to explain and justify their role and standpoint frequently (Turner, 1978: 15). This strengthens the correlation between the attractiveness of the image and the strength of identification. The desire to create an impression for others that is consistent with the construed external image is also more intense when one's organization affiliation is visible. This strengthens the correlation between the attractiveness of the construed external image and the strength of identification. Both arguments support the eighth proposition:

Proposition 8 (P8): The greater the visibility of a member's affiliation with the organization, the stronger the relationship between the attractiveness of the construed external image and a member's organizational identification.

Figure 1 summarizes our model of how perceived organizational identity and the construed external image are linked to the strength of a member's identification with the organization. 
Figure 1. Linking perceived organizational identity and construed external image to strength of organizational identification.

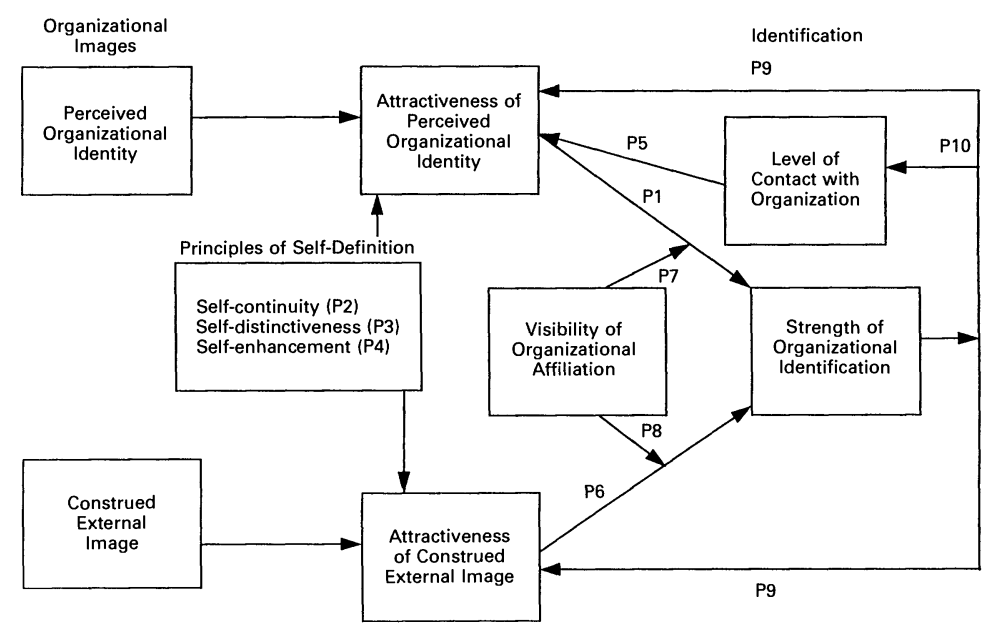

\section{CONSEQUENCES OF ORGANIZATIONAL IDENTIFICATION}

Organizational identification has several consequences for individuals' beliefs and behaviors. Using the model of member identification developed thus far, we will discuss these consequences to explain more fully how the process we model affects the organization, its members, and even the world outside it.

\section{Strengthening the Antecedents of Organizational Identification}

Research on self-affirmation processes (Steele, 1988) and self-justification processes (Staw, 1980) indicates that people attempt to preserve a sense of integrity and self-worth. These beliefs about the self are sustained by positively evaluating the groups with which one identifies, including the organization. As mentioned earlier, one consequence of organizational identification is the strengthening of its antecedents. As members identify more strongly with the organization, their beliefs about the organization are likely to become more positive. Members who strongly identify with an organization are likely, for example, to believe that the organization is producing valuable outputs. A particular consequence of this tendency to evaluate the organization more positively is that the attractiveness of the perceived organizational identity and construed external image are likely to increase.

Proposition 9 (P9): The greater the strength of organizational identification, the more members will evaluate the perceived organizational identity and construed external image as attractive.

The feedback loops in Figure 1 which connect strength of organizational identification to attractiveness of the perceived organizational identity and the construed external image, depict the effect of organizational identification on its antecedents.

In addition to affecting beliefs, strong organizational identification affects behaviors. These behaviors also strengthen the antecedents of organizational identification. 
The logic of self-perception helps to explain this reinforcing cycle. People are motivated to maintain consistency between their self-perceptions and behavior (Festinger, 1957), and those who strongly identify with an organization will seek more contact with the organization. More contact with the organization enhances the sense of continuity of one's self-concept that people value. Kunda's (1992) account of the behaviors of the strongly identified engineers at Tech described how they worked to increase their contact with and submersion in the organization by depicting themselves as Tech members. One memorable example is Mary:

Mary is unmarried. Over the desk, where others keep family pictures there is a glossy picture of her at a trade show with colleagues. A row of ribbons and name tags from various such events are pinned to the wall next to it. Above it is an 'I love Tech' bumper sticker. On a shelf there is a golf section with a few trophies. 'Most Improved Golfer' from Golfer's Digest and a Tech trophy. Next to it a color print of a sailing boat with a large Tech logo in the billowing sail. An orderly row of beer bottles and mugs with a Tech logo, all with their handles facing left. (p. 194)

These arguments suggest another proposition that links the strength of organizational identification to one of its antecedents:

Proposition 10 (P10): The greater the strength of organizational identification, the more a member will seek contact with the organization.

\section{Patterns of Social Interaction}

Strong identification with the organization keeps members attuned to the future viability of the organization. When people strongly identify with their work organization their sense of survival is tied to the organization's survival. This link has at least two effects. One effect involves interpersonal dynamics: Strong identification prompts increased cooperation with organizational members as part of the organizational group and increased competition with nonmembers. Second, members direct additional effort toward tasks that contribute to coworkers and to the organization.

When a member's level of organizational identification is strong, his or her sense of self as an organizational member helps to form a pattern of in-group and out-group dynamics. While these dynamics play out between units within an organization (Ashforth and Mael, 1989), they can also explain differences in members' behavior across organizations. In early studies of intergroup discrimination, Tajfel et al. (1971) designed an experiment in which subjects were separated into groups by random criteria and were told only about their group affiliation. Even under this stripped-down condition, now known as the minimal group paradigm, subjects discriminated in favor of in-group members and against out-group members. Social identification theory explains that the perception of a shared categorical identity creates an in-group bias, which leads to intragroup cohesion (Turner, 1978; Kramer, 1991), through the accentuation of perceived similarities with other group members (Hogg and Abrams, 1988) and the resulting positive attitudes toward these in-group members (Turner, 1978: 28). Strong identification with an organization makes cooperative behavior toward 
other organizational members likely because of a heightened sense of in-group (organizational) trust and reciprocity, heightened social attraction toward in-group members, and presentation of a favorable image of the organization to self and others (Kramer, 1991):

Proposition 11 (P11): The stronger the organizational identification, the greater a member's cooperation with other members of the organization (in-group cooperation).

When people identify themselves as organizational members they rely on organizational-level categories to determine the relevant in-groups and out-groups. Along with increasing the cooperativeness among people perceived as being part of the organizational in-group, identification increases the competitiveness that organizational members perceive between themselves (as the in-group) and other out-groups.

Ample empirical evidence links intergroup-level categorization with the emergence of competitive behaviors between groups (see Hogg and Abrams, 1988; Kramer, 1991, for reviews). Although intergroup differentiation does not necessarily cause competition, in our culture, competition between groups is relatively easy to trigger (Hogg and Abrams, 1988). Within the minimal group paradigm, simply categorizing people into groups has been shown to be sufficient to produce competitive behavior between people in different groups (Tajfel et al., 1971). Further, in interdependent social situations in which one group "wins" something valued only when other groups "lose," members who identify with the organization are more aware of the collective consequences of winning and are thus more competitive with out-group members than are members who don't identify with the organization. This logic supports the twelfth proposition:

Proposition 12 (P12): The greater the strength of organizational identification, the greater a member's competitive behavior directed toward out-group members.

Along with cooperation between members, other patterns of interaction also change. People who strongly identify with the organization are likely to focus on tasks that benefit the whole organization rather than on purely self-interested ones. This is organizational citizenship behavior.

Organizational citizenship behaviors are organizationally functional behaviors that extend beyond role requirements and are not contractually guaranteed (Smith, Organ, and Near, 1983; Organ, 1990). O'Reilly and Chatman's (1986) studies demonstrated a positive correlation between attachment based on internalization and identification and levels of extrarole behavior, which indirectly supports this assertion even though they defined and measured the two forms of attachment (identification and internalization) in ways that differ from the strength of identification. As members become more psychologically attached to an organization, their relationship to the organization changes, resulting in systematically different behavioral displays of psychological involvement. Mael and Ashforth (1992) found some evidence of this relationship in their study of alumni's identification with their alma mater. They found that more organizational identification correlated with the ranked priority of contributions and advising one's son and others to 
attend an all-male, religious college. We suggest that effort directed toward preserving, supporting, and improving the organization proceeds naturally from the congruence between a member's self-definition and the organization's definition. Organizational identification aligns individual interests and behaviors with interest and behaviors that benefit the organization. It means exertion on behalf of the organization is also exertion on behalf of the self (Shamir, House, and Arthur, 1993).

Members' efforts to benefit the organization result in behaviors that are acts of obedience, loyalty, and participation, such as spending time helping newcomers, working on long-term organizational projects, pushing superiors to perform to higher standards, and providing ideas for improving the organization (Van Dyne, Graham, and Dienesch, 1994). Strong organizational identification enables members to contribute more frequently and more freely to the organization. When strong overlap exists between what defines the person and what is thought to define the organization, this overlap enables a member to contribute simultaneously to him- or herself and to the organization:

Proposition 13 (P13): The stronger the organizational identification, the more often a member exhibits organizational citizenship behaviors.

\section{DISCUSSION}

In this paper we assert that images of organizations shape how members define themselves. When members define themselves with attributes that overlap with the attributes they use to define the organization, they are strongly identified with the organization. Strong identification with an organization is also apparent when the social identity of an organization is more available and salient than other social identities.

The psychology of social identity theory is powerful because it implies that members may change their behavior by merely thinking differently about their employing organization. If members believe that the perceived organizational identity has been altered either in content (e.g., in what attributes distinguish this organization) or in its evaluation (making it more or less attractive), members are likely to modify their behavior. This change in members' behavior does not require interacting with others, altering employees' jobs and rewards, or changing bosses. Rather, if members think of their employing organization differently (by changes in the perceived organizational identity or construed external image), we argue they will behave differently.

Organizational images shape the strength of members' identification with the organization, serving as important cognitive reference points that either connect or disconnect a member from the organization. When the images are attractive, they increase the degree to which self-definitions approximate the organizational definition. Members' images of their employing organization are vital sources of their self-construction. By providing members with images of the social group to which they belong that specify the content of 
what it means to be a member, organizations provide vital input for members' self-definition.

The model shows how the construed external organizational image affects the level of connection between individuals and their organizations. By doing so, it brings the insights of symbolic interactionists into depictions of individual attachment to organizations. Symbolic interactionists assert that organizational members come to know themselves through the impressions of others and that these anticipated impressions shape people's everyday behavior. This assertion implies that there are attachment consequences to believing that outsiders see the organization in a particular way. By examining the relationships between construed external image and members' identification, we recognize that individual-organizational attachment is more than an intrapersonal phenomenon. Members' degree of cognitive attachment (e.g., strength of identification) to the organization links to the anticipated reflected appraisal by others, making cognitive attachment a social and interpersonal process as well.

Our model is relevant to three approaches in research on organizational impression management. One approach uses attribution theory to look at organizational accounts for success and failure (Salancik and Meindl, 1984). Another focuses on how organizations construe actions and events to maintain a positive image in the minds of key stakeholders (Sutton and Kramer, 1990; Elsbach and Sutton, 1992; Ginzel, Kramer, and Sutton, 1993). And a third concentrates on the content and effectiveness of organizational image management (Elsbach, 1994). All three approaches emphasize leaders' and organizational efforts to create organizational images and acknowledge that these images affect outside stakeholders' impressions of an organization's legitimacy. This literature ignores how these images affect organizational insiders-the members who are associated with these images as part of their everyday work behavior. Our model suggests that researchers interested in the social psychology of organizational impression management should consider how the images created for outsiders shape the experience, attachments, and behaviors of insiders.

\section{Future Research}

Extending and testing the model presented in this paper requires operationalizing strength of organizational identification. There are at least three different approaches to measuring this variable. The first strategy involves directly assessing one's organizational identification. Mael and Ashforth (1988) developed a scale-based measure of strength of organizational identification that is reliable and empirically distinguishable from concepts such as organizational commitment and involvement, but, like O'Reilly and Chatman's (1986) operationalization, their scale includes assessments of how individuals feel about the organization. By involving more than the cognitive connection between a member and an organization, these scales tap into a broader concept of psychological attachment than what we intend by organization 
identification. A possible alternative might be to modify Jackson's (1981) index of commitment to an identity index that uses an array of items to assess the importance of a given social identity to a member's self-definition.

A second strategy would be to ask members to evaluate a set of social identities and indicate the relative degree to which these identities accurately describe them as individuals, either by rating each identity or ranking them in a hierarchy (e.g., Hoelter, 1985; Harquail, 1994). Using this approach, strong organizational identification is indicated when a person ranks or rates the organizational identity higher than other social identities.

A third approach involves directly assessing the level of overlap between the characteristics that a member believes typify him or her as an individual (i.e., are enduring, central, and distinctive) and the characteristics that typify the organization. High levels of overlap between the two lists of central, distinctive, and enduring attributes would indicate strong organizational identification.

Research assessing the strength of organizational identification should also address the desirable and undesirable outcomes associated with strong organizational identification. For example, Ashforth and Mael (1992) presented a study in which they found that strong organizational identification was associated with tyrannical behavior of managers toward their subordinates, such as belittling of subordinates and increased use of noncontingent punishment. Their results are unsettling and add credence to warnings about the dark side of organizational identification (Schwartz, 1987; Kunda, 1992).

Future research should consider the array of organizational images that may affect members' attachments to an organization. We have not treated all organizational images that have currency in an organization as equal but, rather, have singled out perceived organizational identity and construed external image as particularly important and worthy of empirical study. Also, while we have considered only members' present images of the organization, psychologists and organizational researchers have shown that future-based images of the organization-what Gioia and Thomas (1991) and Reger et al. (1994) called the ideal organization or what Whetten, Lewis, and Mischel (1992) called the desired organization image-also shape members' behaviors in organizations. The concept of "possible selves" discussed by Markus and Nurius (1986) suggests one avenue for exploring how these future images of organizations shape members' behavior by affecting the content and evaluation of possible selves. This concept describes individuals' ideas about what they might become and what they are afraid of becoming and can provide a conceptual link between self-schema and members' motivations (Markus and Nurius, 1986: 954). Future research should elaborate how future and past images of the organization connect to a member's self-concept and direct his or her behavior.

We also need research on how changing conditions affect members' images of their work organization and the 
behaviors that result. Changes in structure, culture, organizational performance, organizational boundaries, or an organization's competitive strategy may induce members to revise their perceived organizational identity and construed external image. These redefinitions could have significant psychological effects. A decline in organizational performance, for example, may lower the perceived attractiveness of the organization's construed external image, weakening organizational identification and creating less cooperation and fewer organizational citizenship behaviors.

Mergers and acquisitions represent changes in both structure and culture and may alter members' organizational images. These strategic changes revise both the boundaries and the content of a member's perceived organizational identity. When the retail discount giant, KMart, bought the upscale and highbrow Borders bookstores, employees' sense of the perceived organizational identity changed, as did the construed external image (Bridgeforth, 1992). Some employees believed that the basis for the distinctiveness of Borders-its ability to attract "readers with discriminating tastes" - would be compromised by its association with a large discount store (Bridgeforth, 1992: C1). Based on our model, we would predict that some Borders employees would weaken their level of organizational identification, resulting in fewer displays of affiliation, less cooperative behavior with inside members, fewer organization citizenship behaviors, and a host of other outcomes. Alternatively, the model suggests that if the perceived organizational identity does change, and Borders members spend a large amount of time seeing themselves as part of this changed social group (a KMart-Borders), then, over time, members may alter how they see themselves.

Future researchers should consider the relationship between members' perceived organizational identity and their expectations about organizational actions, which would help us understand how members respond when the organization's actions exceed or fail to meet their expectations. Members expect the organization's actions to reflect what is distinctive, central, and enduring about the organization's identity, and they discern their organization's identity in part by interpreting the organization's actions (Dutton and Dukerich, 1991). When members who identify with an organization observe a consistency between expected and actual organizational actions, their organizational identification strengthens because the organizational identity proves to be a reliable source of self-definition.

When members perceive major inconsistencies between expected and actual organizational actions, a different set of responses is likely. As suggested by balance theory (Heider, 1958), self-perception theory (Bem, 1967), and cognitive dissonance theory (Festinger, 1957), members will work to resolve this inconsistency (Turner and Oakes, 1986). One response involves downplaying the importance of these inconsistencies by offering excuses or justifications (Bies and Sitkin, 1991), with no major change in the strength of their organizational identification. Another response involves 
revising one's perceptions of the organization's identity. If this revision enhances the attractiveness of the perceived identity, member identification will be strengthened. Conversely, if the revision erodes the attractiveness of the identity, members' identification will weaken. A third possible response implies that members experience these inconsistencies as threats to their own identities and respond by changing their self-definitions (Breakwell, 1986).

Finally, we must consider the generalizability of this model of organizational identification to different national or societal contexts. Our model is built on a conceptualization of the self that assumes that people want to become "independent from others and to discover and express their own uniqueness" (Markus and Kitayama, 1991: 226). This assumption about how a person's self is organized underlies the hypothesized links between perceived organizational identity, construed external image, strength of organizational identification, and individual-level outcomes, but this assumption may be limited in its cultural generalizability (Erez and Earley, 1993). Markus and Kitayama (1991: 227) explained how an alternative view of self-one that is built on the "fundamental connectedness of human beings to each other" and one that is typically associated with non-Western cultures-may create very different connections between an organization and an individual's beliefs and actions. When Japan Air Lines (JAL) experienced the worst single aircraft accident ever (520 people were killed), the president, Yasumoto Takagi, "'followed Japanese custom and took responsibility for the crash by resigning" (Los Angeles Times, 1985: 2). Organizational members in non-Western cultures may feel accountable for the images that are created of their organization, thus implying an even stronger connection between these images and subsequent behaviors.

This paper shows that it is more than economic transactions that connect members to their work organizations.

Members' attachments to an organization are fundamentally tied both to the images that they have of what the organization means to them and what they think it means to others. If the images provide them with continuity, distinctiveness, or positive evaluations, then their attachments strengthen through organizational identification. Economic depictions of organizational attachments ignore these images and their dynamic qualities. Our model suggests that these images should be at center stage if we are to understand what makes the $3 \mathrm{M}$ salesman get up eagerly for work in the morning and see new possibilities and meaning in his life as an organizational member.

\section{REFERENCES}

Albert, Stuart, and David A. Whetten

1985 "Organizational identity." In L. L. Cummings and Barry $M$. Staw (eds.), Research in Organizational Behavior, 7: 263-295. Greenwich, CT: JAI Press.
Alderfer, Clayton P., and Kenwyn K. Smith

1982 "Studying intergroup relations embedded in organizations." Administrative Science Quarterly, 27: 35-65.
Allaire, Yvan, and Michael E. Firsirotu

1984 "Theories of organizational culture." Organization Studies, 5: 193-226. 
Arora, R. G., and S. T. Cavusgil

1985 "Image and cost factors in the choice of mental health-care organizations: A causal model." Journal of Academy of Marketing Science, 13: 119-129.

Ashforth, Blake E., and Fred Mael

1989 "Social identity theory and the organization." Academy of Management Review, 14: 20-39.

1992 "The dark side of organizational identification." Paper presented at the Academy of Management Meeting, Las Vegas.

Bem, Daryl J.

1967 "Self-perception: The dependent variable of human performance." Organizational Behavior and Human Performance, 2: 105-121.

Bies, Robert J., and Sim B. Sitkin

1991 "Explanation as legitimation: Excuse-making in organizations." In M. McLaughlin, M. Cody, and S. Read (eds.), Explaining One's Self to Others: Reason-giving in a Social Context: 183-198. Hillsdale, NJ: Erlbaum.

Boorstin, Daniel

1961 The Image: A Guide to Pseudo-events in America. New York: Atheneum.

Breakwell, Glynis $M$.

1986 Coping with Threatened Identities. New York: Metheun.

Bridgeforth, Arthur, Jr.

1992 "Bordering on change: Borders bookstore chain turns a page in its history, but won't close the book on providing good reading." Ann Arbor News, October 25, C1.

Brockner, Joel

1988 Self-esteem at Work: Research, Theory and Practice. Lexington, MA: D.C. Heath.

Brown, Michael E.

1969 "Identification and some conditions of organizational involvement." Administrative Science Quarterly, 14: 346-355.

Bruner, Jerome S.

1957 "Going beyond the information given." In $\mathrm{H}$. Gruber, K. Hammond, and R. Jessor (eds.), Contemporary Approaches to Cognition: 41-69. Cambridge, MA: Harvard University Press.
Charters, W. W., and Theodore M.

Newcomb

1952 "Some attitudinal effects of experimentally increased salience of group membership." In G. E. Swanson et al. (eds.), Readings in Social Psychology: 415-420. New York: Holt, Rinehart and Winston.

Chatman, Jennifer A.

1991 "Matching people and organizations: Selection and socialization in public accounting firms." Administrative Science Quarterly, 36: 459-484.

Cheney, George

1983 "On the various and changing meanings of organized membership: A field study of organizational identification." Communication Monographs, 50: 342-362.

Cialdini, Robert B., Richard J. Borden, Avril Thorne, Marcus

Randall Walker, Stephen Freeman and Lloyd Reynolds Sloan

1976 "Basking in reflected glory: Three (football) field studies." Journal of Personality and Social Psychology, 34 366-375

Dutton, Jane E.., and Janet M.

Dukerich

1991 "Keeping an eye on the mirror: The role of image and identity in organizational adaptation." Academy of Management Journal, 34: 517-554.

Elsbach, Kimberly D.

1994 "Managing organizational legitimacy in the California cattle industry: The construction and effectiveness of verbal accounts."

Administrative Science Quarterly, 39: 57-88.

Elsbach, Kimberly D., and Robert I. Sutton

1992 "Acquiring organizational legitimacy through illegitimate actions: A marriage of institutional and impression management theories." Academy of Management Journal, 35: 699-738.

Erez, Miriam, and P. Christopher

Earley

1993 Culture: Self-Identity and Work. New York: Oxford University Press.

Fanning, D.

1990 "Coping in industries that the public hates." New York Times, August 19: F 25.
Feldman, Daniel C

1976 "A contingency theory of socialization." Administrative Science Quarterly, 21 433-452.

Festinger, Leon

1957 A Theory of Cognitive Dissonance. New York: Harper and Row.

Fiol, Marlene

1991 "Managing culture as a competitive resource: An identity-based view of sustainable competitive advantage." Journal of Management, 17: 191-206.

Foote, Nelson $\mathrm{N}$.

1953 "Identification as a basis for a theory of motivation." American Sociological Review 16: 14-21.

Garbett, Thomas

1988 How to Build a Corporation's Identity and Project Its Image. Lexington, MA: D.C. Heath.

Gatewood, Robert D., Mary A.

Gowan, and G. J. Lautenschlager

1993 "Corporate image, recruitment image, and initial job choice decisions." Academy of Management Journal, 36: 414-427.

Gecas, Viktor

1982 "The self-concept." In R. H. Turner and J. F. Short, Jr. (eds.), Annual Review of Sociology, 8: 1-33. Palo Alto, CA: Annual Reviews.

Gergen, Kenneth J.

1968 "Personal consistency and the presentation of self." In Chad Gordon and K. J. Gergen (eds.), The Self in Social Interaction, 1: 299-308. New York: Wiley.

Ginzel, Linda E., Roderick M. Kramer, and Robert I. Sutton

1993 "Organizational impression management as a reciprocal influence process: The neglected role of the organizational audience." In L. L. Cummings and Barry M Staw (eds.), Research in Organizational Behavior, 15: 227-266. Greenwich, CT: JAI Press.

Gioia, Dennis A., and James B. Thomas

1991 "Sensemaking, sensegiving and action taking in a university: Toward a model of strategic interpretation." Paper presented at the Academy of Management Meeting, Miami. 
Greenberg, Jerald

1990 "Looking fair versus being fair: Managing impressions of organizational justice." In Barry M. Staw and L. L. Cummings (eds.), Research in Organizational Behavior, 12: 111-157. Greenwich, CT: JAI Press.

Hall, Douglas T., and Benjamin

Schneider

1972 "Correlations of organizational identification as a function of career pattern and organizational type." Administrative Science Quarterly, 17: 340-350.

Hall, Douglas T., Benjamin Schneider, and Harold T. Nygren 1970 "Personal factors in organizational identification." Administrative Science Quarterly, 17: 340-350

Harquail, Celia V.

1994 "Is sisterhood powerful? Social identification and women's advocacy in organizations." Unpublished Ph.D. dissertation proposal, University of Michigan.

Heider, Fritz

1958 The Psychology of Interpersonal Relations. New York: Wiley.

Hirschman, Albert 0.

1970 Exit, Voice and Loyalty: Responses to Decline in Firms, Organizations and States. Cambridge, MA: Harvard University Press.

Hoelter, Jon W.

1985 "The structure of self-conception:

Conceptualization and measurement." Journal of Personality and Social Psychology, 48: 1392-1407.

Hogg, Michael A., and Dominic Abrams

1988 Social Identifications: A Social Psychology of Intergroup Relations and Group Processes. London: Routledge.

Jackson, Susan E.

1981 "Measurement of commitment to role identities." Journal of Personality and Social Psychology, 40: 138-146.

Kahn, William A.

1990 "Psychological conditions of personal engagement and disengagement at work." Academy of Management Journal, 33: 692-724.
Kelman, Herbert C.

1958 "Compliance, identification and internalization." Journal of Conflict Resolution, 2: 51-60.

Kramer, Roderick $M$.

1991 "Intergroup relations and organizational dilemmas: The role of categorization processes." In L. L.

Cummings and Barry M. Staw (eds.), Research in

Organizational Behavior, 13: 191-228. Greenwich, CT: JAI Press.

Kunda, Gideon

1992 Engineering Culture. Philadelphia: Temple University Press.

Lee, Sang $M$.

1971 "An empirical analysis of organizational identification." Academy of Management Journal, 14: 213-226.

Los Angeles Times

1985 "JAL replaces top officers in shake-up over crash." December 19, part 4: 2.

Mael, Fred, and Blake E. Ashforth

1988 "A reconceptualization of organizational identification." In T. L. Keon and A. C. Bluedorn (eds.), Proceedings of the Midwest Academy of Management Meetings: 127-129.

1992 "Alumni and their alma mater: A partial test of the reformulated model of organizational identification." Journal of Organization Behavior, 13: 103-123.

Markus, Hazel R., and Shimbu Kitiyama

1991 "Culture and the self: Implications for cognition, emotion and motivation." Psychological Review, 98: 224-253.

Markus, Hazel R., and Paula

Nurius

1986 "Possible selves." American Psychologist, 41: 954-969.

Markus, Hazel R., and Elissa Wurf

1987 "The dynamic self-concept: A social-psychological perspective." In Mark R. Rosenzweig and Lyman W. Porter (eds.), Annual Review of Psychology, 38: 299-337.

Palo Alto, CA: Annual Reviews.

Martin, Joanne, Martha S. Feldman, Mary Jo Hatch, and Sim B. Sitkin

1983 "The uniqueness paradox in organizational stories." Administrative Science Quarterly, 28: 438-453.
Mowday, Richard, Lyman M.

Porter, and Richard M. Steers

1982 E-O Linkages: The Psychology of Commitment, Absenteeism and Turnover. New York: Academic Press.

O'Reilly, Charles, and Jennifer

Chatman

1986 "Organizational commitment and psychological attachment: The effects of compliance, identification and internalization on prosocial behavior." Journal of Applied Psychology, 71: 492-499.

O'Reilly, Charles, Jennifer Chatman, and David F. Caldwell

1991 "People and organizational culture: A profile comparison approach to assessing person-organization fit." Academy of Management Journal, 34: 487-516.

Organ, Dennis W.

1990 "The motivational basis of citizenship behavior." In Barry M. Staw and L. L. Cummings (eds). Research in Organizational Behavior, 12 : 43-72. Greenwich, CT: JAI Press.

Perrow, Charles

1961 "Organizational prestige Some functions and dysfunctions." American Journal of Sociology, 61 : 373-391.

Pfeffer, Jeffrey

1981 "Management as symbolic action." In L. L. Cummings and Barry M. Staw (eds.), Research in Organizational Behavior, 3: 1-52. Greenwich, CT: JAI Press.

Porter, Lyman W., Richard M.

Steers, Richard T. Mowday, and

Paul V. Boulian

1974 "Organizational commitment job satisfaction and turnover among psychiatric technicians." Journal of Applied Psychology, 59: 603-609.

Reger, Rhonda K., Loren T. Gustafson, Sam M. DeMarie, and John V. Mullane

1994 "Reframing the organization: Why implementing Total Quality is easier said than done." Academy of Management Review, vol. 19 (in press).

Salancik, Gerald R., and James R. Meindl

1984 "Corporate attributions as strategic illusions of management control." Administrative Science Quarterly, 29: 238-254. 
Schlenker, Barry R.

1985 "Self-identification: Toward an integration of the private and public self." In R. Baumiester (ed.), Public Self and Private Self: 21-62. New York: Springer-Verlag.

Schwartz, Howard S.

1987 "Anti-social actions of committed organizational participants: An existential psychoanalytic perspective." Organization Studies, 8 : 327-340.

Selame, Elinor, and Joe Selame

1988 The Company Image: Building Your Identity and Influence in the Marketplace. New York: Wiley.

Shamir, Boas

1991 "Meaning, self and motivation in organizations." Organization Studies, 12: 405-424.

Shamir, Boas, Robert J. House and Michael B. Arthur

1993 "The motivational effects of charismatic leadership: A self-concept based theory." Organization Science, 4: 577-594.

Smith, Ann C., Dennis W. Organ, and Janet P. Near

1983 "Organizational citizenship behavior: Its nature and antecedents." Journal of Applied Psychology, 68: 653-663.

Star Ledger (Newark)

1989 "Exxon workers assailed." May 22: 3

Staw, Barry M.

1980 "Rationality and justification in organizational life." In Barry M. Staw and L. L. Cummings (eds.), Research in Organizational Behavior, 2: 45-80. Greenwich, CT: JAI Press.

Steele, Claude M.

1988 "The psychology of self-affirmation: Sustaining the integrity of the self." In Leonard Berkowitz (ed.) Advances in Experimental Social Psychology, 21: 261-302. New York: Academic Press.

Stern, S.

1988 "A symbolic representation of organizational identity." In Michael O. Jones, Michael D. Moore, and Richard C. Snyder (eds.), Inside Organizations: 281-295. Newbury, CA: Sage.

\section{Member Identification}

Stryker, Sheldon, and Richard T. Serpe

1982 "Commitment, identity salience and role behavior: Theory and research example." In W. Ickers and E. Knowles (eds.), Personality, Roles and Social Behavior: 199-219. New York: Springer-Verlag.

Sutton, Robert I., and Roderick M Kramer

1990 "Transforming failure into success: Impression management, the Reagan Administration, and the Iceland Arms Control Talks." In Robert L. Kahn and Mayer Zald (eds.), International Cooperation and Conflict Perspectives from Organization Theory: 221-245. San Francisco: Jossey-Bass.

Tajfel, Henri

1982 "Social psychology of intergroup relations." In Mark R. Rosenzweig and Lyman W. Porter (eds.), Annual Review of Psychology, 33: 1-39. Palo Alto, CA: Annual Reviews.

Tajfel, Henri, C. Flament, M. G. Billig, and R. F. Bundy

1971 "Social categorization and intergroup behavior." European Journal of Social Psychology, 1: 149-177.

Tajfel, Henri, and John C. Turner

1985 "The social identity theory of intergroup behavior." In Steven Worchel and William G. Austin (eds.), Psychology of Intergroup Relations, 2: 7-24. Chicago: Nelson-Hall.

Tetlock, Philip E., and Anthony S. Manstead

1985 "Impression management versus intrapsychic explanations in social psychology: A useful dichotomy?" Psychological Review, 92: 59-77.

Turner, John C.

1982 "Towards a cognitive redefinition of the social group." In Henri Tajfel (ed.), Social Identity and Intergroup Relations: 15-40. Cambridge: Cambridge University Press.
Turner, John C., and Penelope J. Oakes

1986 "The significance of the social identity concept for social psychology, with reference to individualism, interactionism and social influence." British Journal of Social Psychology, 25: 237-252.

Turner, Ralph $\mathrm{H}$.

1978 "The role and the person." American Journal of Sociology, 84: 1-23.

Van Dyne, Linn, Jill W. Graham, and Richard M. Dienesch

1994 "Organizational citizenship behavior: Construct redefinition, operationalization and validation." Academy of Management Journal, vol. 37 (in press).

Van Maanen, John

1975 "Police socialization: A longitudinal examination of job attitudes in an urban police department." Administrative Science Quarterly, 20: 207-228.

Van Maanen, John, and Stephen

R. Barley

1984 "Occupational communities: Culture and control in organizations." In Barry M. Staw and L. L. Cummings (eds.), Research in Organizational Behavior, 6: 287-365. Greenwich, CT: JAl Press.

Van Maanen, John, and Edgar $\mathrm{H}$. Schein

1979 "Toward a theory of organizational socialization." In Barry M. Staw and L. L. Cummings (eds.), Research in Organizational Behavior, 1: 209-264. Greenwich, CT: JAI Press.

Vardi, Yoav, Yoash Wiener, and

Micha Poppa

1989 "The value content of organizational mission as a factor in the commitment of members." Psychological Reports, 65: 27-34.

Whetten, David A., Debra Lewis, and Leann Mischel

1992 "Towards an integrated model of organizational identity and member commitment." Paper presented at Academy of Management Meeting, Las Vegas. 